\title{
Construction of an Instrument for the Evaluation of the Effects of Information and Communication Technologies among Young People
}

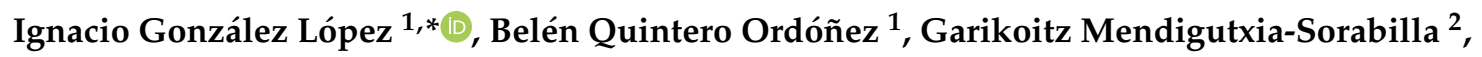 \\ Eloísa Reche Urbano ${ }^{3}{ }^{-1}$ and Juan Antonio Fuentes Esparrell ${ }^{4}$ \\ 1 Department of Education, University of Córdoba, 14071 Córdoba, Spain; bquintero@uco.es \\ 2 National Prevention Committee, Proyecto Hombre Association, 28027 Madrid, Spain; \\ suspertu@proyectohombrenavarra.org \\ 3 Department of Artistic and Body Education, University of Córdoba, 14071 Córdoba, Spain; fe1reure@uco.es \\ 4 Department of Didactic and School Organization, University of Granada, 18071 Granada, Spain; \\ fuentese@ugr.es \\ * Correspondence: ignacio.gonzalez@uco.es; Tel.: +34-957-218-962
}

Received: 1 April 2020; Accepted: 30 April 2020; Published: 7 May 2020

check for updates

\begin{abstract}
The aim of this paper is to investigate the issue of access to Information and Communication Technologies (ICT) at younger ages, which is leading to dependency on mobile phones, video games, and compulsive aimless internet surfing - an issue that schools have been increasingly seeking to tackle. With the appearance of emerging technologies, and not forgetting those already established, an instrument is required that will adapt to new casuistry and help to design intervention programmes in accordance with present and future patterns of use, abuse, and addiction. Studies such as the one proposed here will provide data about the profile of this population in order to improve programmes and influence the ICT policies rolled out by central and local governments. The chief aim of this paper is to construct and validate an instrument capable of evaluating problems experienced by young people in relation to technology use, abuse, and addiction within the programmes developed in Spain. The research design used in this study is mixed empirical, non-experimental, and sequential in nature in three stages: interviews conducted with 11 prevention professionals, group of 11 experts and pilot group of 30 participants in indicated prevention programmes. The findings of the study indicate that the instrument fulfills the parameters established to be considered a systematic empirically sustainable instrument, since the young population needs to identify these patterns in order to understand and prevent risk behaviours associated with their use.
\end{abstract}

Keywords: techno-addiction; indicated prevention; evaluation; young people

\section{Introduction}

The technological developments experienced over the past decade have brought forth a wide range of devices, applications, and tools designed for recreation, communication, and the services sector, becoming essential activities that facilitate everyday life. However, in some cases, their use has fuelled different types of repetitive, addictive or abusive behaviours, and this phenomenon has been studied within various disciplines such as psychology, education, and sociology [1-5].

Some studies have shown that access to Information and Communication Technologies (ICT) at increasingly young ages can make subjects more prone to inappropriate usage, triggering dependency on mobile phones, video games, compulsive aimless internet surfing, social media, or instant messaging apps. 
As noted by Matalí, García, Marín and Pardo [6], when technology changes from being a means to an end in itself, we become subject to a situation of dependency, and even addiction. Great social alarm has been generated about the addiction to new technologies in adolescents, which is reflected in various studies [7-13]. When use of such technology is high but controlled, we talk about problematic usage, taking as a basis the data provided by the Pfizer Foundation's study conducted in 2009 [14], which indicated that $98 \%$ of young Spanish people aged 11-20 used the internet, and of these, around $3 \%-6 \%$ spent an average of 1.5 hours a day online. Along these lines, the report published in 2015 by the Organisation for Economic Co-operation and Development (OECD) [15] showed that Spanish students spent an average of 2 hours 20 minutes a day online, a much higher figure than advised. Spain's National Institute of Statistics [16] signalled that 95\% of Spanish teenagers, ranging in age from 10 to 15, went online every day. In any case, when dealing with digital or internet devices and/or the tools that require them in order to be used, the term techno-addiction can be used [17].

Adolescence is characterised by a prioritisation of immediate gratification and living in the present. Teenagers believe they are invincible, and they are interested in new stimulating and risky experiences, which makes them more susceptible to engaging in high-risk behaviours $[18,19]$. They have difficulty controlling their impulses, they are easily influenced by the media and advertising, and drug taking during adolescence can be linked with increased internet use or video gaming [20].

Various risk factors are related to maladaptive or problematic usages of ICTs [21-23].

The results of Chen, Ho and Lwin's [24] research revealed that risky information and communications technology (ICT) use, moral disengagement, social norms, and traditional bullying perpetration were the main predictors of cyberbullying perpetration, while risky ICT use and traditional bullying victimization were the major contributors of cyberbullying victimization (Gossip, Cyber-baiting, Happy Slapping ... ).

In order to examine these phenomena, a variety of instruments has been developed to measure the prevalence, abuse or problematic use of ICT among teenagers and students, largely associated with web surfing, the use of mobile phones, the consumption of television, and video-gaming [25,26]. López-Fenández, Freixa-Blanxart and Honrubia-Serrano [27] reviewed the available scales for assessing problematic internet use and to validate a new scale about the Problematic Internet Entertainment Use for Adolescents. However, with the appearance of emerging technologies, not forgetting the established ones, an instrument is required that will adapt to new casuistry and help to design intervention programs in accordance with present and future patterns of use, abuse, and addiction [17,22,23].

For more than 20 years, Proyecto Hombre has been helping families who ask for support with regard to problems affecting their children. It runs indicated prevention programs for young people. According to the European Monitoring Centre for Drugs [28], Indicated Prevention involves identifying and intervening with young people who present indicators that are highly correlated with the risk of developing problems related with drug-taking and other risk behaviours over the course of their lives, or who present early drug consumption patterns. Hence, the aim is not only to prevent young people from taking drugs in the first place, but also to prevent the development of dependency, decrease the frequency of use, or prevent progression towards more harmful consumption patterns or risk behaviours.

The main goal of this paper is to construct and validate an instrument, to be used with young people, in order to evaluate potential problems with regard to technology use, abuse, and addiction, in indicated prevention programmes run by Proyecto Hombre Association throughout Spain.

\section{Materials and Methods}

The research design used is mixed empirical, nonexperimental and sequential in nature. It will explore relationships by associating and comparing data groups [29]. This design is rooted in the basic premise of a prior exploration, since there are no standardized measurement instruments available or a compendium of theoretically justified variables, prioritizing the compilation of qualitative data as the preliminary stage [30]. It will also help to improve research processes and products [31], 
providing quantifiable and contextual information [32] and allowing for the triangulation of results, the complementary nature of the phenomena studied, the discovery of singularities based on the profiles encountered, the sequencing of instruments designed, and the expansion of the study as we move through each of the stages [33].

Since this is a multi-stage study, the different stages designed to respond to the initially formulated research aim are as follows:

- Stage 1 (Designing a first draft based on the information provided by in-depth interviews conducted with prevention professionals): In order to compile information to construct the instrument aimed at young people involved in indicated prevention programs run by the Proyecto Hombre Association, capable of evaluating possible technology use, abuse or addiction problems; initially, we sought to conduct semi-structured interviews with the programme officers, in order to compile information about the real needs of the professional team working directly with the target study group. Based on the analysis of this information, a first draft of the instrument was developed.

- Stage 2 (Results of the procedure for validating the instruments by means of expert opinion): The tool developed in the previous stage was submitted for validation to a group of experts in the key issues of this project, gathering from them agreement indices for each of the evaluation elements proposed. The result of this activity provided a consensus of responses used to develop a second draft of the tool.

- Stage 3 (Experimental application of the instrument to a pilot group): Having taken on board the recommendations of the experts consulted, the next stage that allowed us to develop the definitive instrument involved applying said instrument to a pilot group. The aim was to identify the reliability and validity of the measures, considering whether the questions were appropriate, whether the wording of the items was correct and comprehensible, whether the questions were of the right length, whether the answers were correctly categorized, whether there was any resistance or psychological barriers or rejection towards any of the questions, whether they were ordered logically, and whether the duration of the questionnaire was acceptable to respondents. This process gave shape to the definitive instrument.

\section{Results}

Below we set out the results of the different stages of this study, showing the process by which, the instrument was progressively constructed.

\subsection{Stage 1: Designing a First Draft Based on the Information Provided by In-depth Interviews Conducted with Prevention Professionals}

The aim of this first stage is to establish the core issues surrounding information and communication technology use, abuse, and addiction among the young people who take part in the indicated prevention programmes run by the Proyecto Hombre Association. Based on this evidence, the foundations can be laid to build an instrument to evaluate this problem systematically and empirically.

Semi-structured interviews were used to access this information, based on 13 questions designed to collate the following data:

- Technological devices used by minors and young people within the indicated prevention programme.

- Activities or tasks they carry out using these devices.

- Knowledge possessed by programme officers about technology use, problematic use and addiction.

- Indicators used to determine technology use, problematic use and addiction in the personal, family, social, education, and occupational or work dimensions.

- Reasons that lead to use, problematic use, or addiction.

- Profile of indicated prevention programme users. 
- Attitude of the family to the consumption of technology.

- Family information required to determine the problem.

- Other necessary information.

The team of indicated prevention programme officers from the Proyecto Hombre Association who took part in this study was 11 women and 4 men from Alicante, Asturias, the Canary Islands, Malaga and Valladolid. With an average age of 38 , and 9 years of professional experience on average, most of these professionals are trained in psychology, although some of them are also trained in primary education teaching or social work.

The interviews were incorporated into the qualitative analysis programme NVivo 11, using the interview questions as key elements when constituting the category tree shown in Table 1.

Table 1. Category tree "Perceptions of Proyecto Hombre officers".

\begin{tabular}{|c|c|c|c|c|c|}
\hline Category & $\mathbf{f}$ & $\%$ & Subcategory & f & $\%$ \\
\hline \multirow{5}{*}{$\begin{array}{l}\text { 1. Devices used } \\
\text { by users of the } \\
\text { indicated } \\
\text { prevention } \\
\text { programme }\end{array}$} & \multirow{5}{*}{57} & \multirow{5}{*}{8} & Video console & 14 & 2 \\
\hline & & & Computer & 11 & 2 \\
\hline & & & Tablet & 9 & 1 \\
\hline & & & Mobile phone & 15 & 2 \\
\hline & & & Television & 8 & 1 \\
\hline \multirow{12}{*}{$\begin{array}{l}\text { 2. Actions or } \\
\text { tasks carried } \\
\text { out using these } \\
\text { devices }\end{array}$} & \multirow{12}{*}{73} & \multirow{12}{*}{10} & Online gambling & 3 & 0 \\
\hline & & & Information searches & 4 & 1 \\
\hline & & & Broadcast channels (YouTube) & 14 & 2 \\
\hline & & & TV and film channels & 5 & 1 \\
\hline & & & Listening to music & 4 & 1 \\
\hline & & & Photos & 1 & 0 \\
\hline & & & Online games & 9 & 1 \\
\hline & & & Phone calls & 2 & 0 \\
\hline & & & Instant messaging & 12 & 2 \\
\hline & & & Social media & 14 & 2 \\
\hline & & & Smart TV & 2 & 0 \\
\hline & & & Video console & 3 & 0 \\
\hline \multirow{4}{*}{$\begin{array}{c}\text { 3. Technology } \\
\text { use, } \\
\text { problematic use } \\
\text { and addiction }\end{array}$} & \multirow{4}{*}{42} & \multirow{4}{*}{6} & Technology addiction & 15 & 2 \\
\hline & & & $\begin{array}{l}\text { Not determined in the dimensions } \\
\text { described }\end{array}$ & 1 & 0 \\
\hline & & & Use & 12 & 2 \\
\hline & & & Problematic use & 14 & 2 \\
\hline \multirow{4}{*}{$\begin{array}{l}\text { 4. Personal } \\
\text { dimension } \\
\text { indicators }\end{array}$} & \multirow{4}{*}{87} & \multirow{4}{*}{12} & Addiction & 29 & 4 \\
\hline & & & $\begin{array}{l}\text { Not determined in the dimensions } \\
\text { described }\end{array}$ & 14 & 2 \\
\hline & & & Use & 22 & 3 \\
\hline & & & Problematic use & 22 & 3 \\
\hline \multirow{4}{*}{$\begin{array}{l}\text { 5. Family } \\
\text { dimension } \\
\text { indicators }\end{array}$} & \multirow{4}{*}{70} & \multirow{4}{*}{9} & Addiction & 17 & 2 \\
\hline & & & Not classified in the dimensions described & 16 & 2 \\
\hline & & & Use & 17 & 2 \\
\hline & & & Problematic use & 20 & 3 \\
\hline \multirow{4}{*}{$\begin{array}{l}\text { 6. Social } \\
\text { dimension } \\
\text { indicators }\end{array}$} & \multirow{4}{*}{69} & \multirow{4}{*}{9} & Addiction & 22 & 3 \\
\hline & & & Not classified in the dimensions described & 9 & 1 \\
\hline & & & Use & 18 & 2 \\
\hline & & & Problematic use & 20 & 3 \\
\hline
\end{tabular}


Table 1. Cont.

\begin{tabular}{|c|c|c|c|c|c|}
\hline Category & $\mathbf{f}$ & $\%$ & Subcategory & f & $\%$ \\
\hline $\begin{array}{l}\text { 7. Education } \\
\text { dimension } \\
\text { indicators }\end{array}$ & 63 & 8 & $\begin{array}{c}\text { Addiction } \\
\text { Not classified in the dimensions described } \\
\text { Use } \\
\text { Problematic use }\end{array}$ & $\begin{array}{l}15 \\
14 \\
17 \\
17\end{array}$ & $\begin{array}{l}2 \\
2 \\
2 \\
2\end{array}$ \\
\hline $\begin{array}{l}\text { 8. Occupational } \\
\text { or work } \\
\text { dimension } \\
\text { indicators }\end{array}$ & 61 & 8 & $\begin{array}{l}\text { Addiction } \\
\text { Not classified in the dimensions described } \\
\text { Use } \\
\text { Problematic use }\end{array}$ & $\begin{array}{l}18 \\
11 \\
16 \\
16\end{array}$ & $\begin{array}{l}2 \\
2 \\
2 \\
2\end{array}$ \\
\hline 9. Reasons & 60 & 8 & $\begin{array}{l}\text { Addiction } \\
\text { Not classified in the dimensions described } \\
\text { Use } \\
\text { Problematic use }\end{array}$ & $\begin{array}{l}14 \\
13 \\
20 \\
13\end{array}$ & $\begin{array}{l}2 \\
2 \\
3 \\
2\end{array}$ \\
\hline $\begin{array}{l}\text { 10. Technology } \\
\text { use profile in } \\
\text { prevention } \\
\text { programmes }\end{array}$ & 54 & 7 & $\begin{array}{l}\text { Technology use profile in prevention } \\
\text { programmes }\end{array}$ & 54 & 7 \\
\hline $\begin{array}{l}\text { 11. Family } \\
\text { attitude }\end{array}$ & 16 & 2 & Family attitude & 16 & 2 \\
\hline $\begin{array}{l}\text { 12. Family } \\
\text { information } \\
\text { required to } \\
\text { specify the } \\
\text { problem }\end{array}$ & 62 & 8 & $\begin{array}{l}\text { Family information required to specify the } \\
\text { problem }\end{array}$ & 62 & 8 \\
\hline $\begin{array}{l}\text { 13. Information } \\
\text { required to } \\
\text { define the } \\
\text { problem }\end{array}$ & 28 & 4 & Information required to define the problem & 28 & 4 \\
\hline Total & 742 & 100 & Total & 742 & 100 \\
\hline
\end{tabular}

Eight percent of the coded text is classified in the category "Devices used by the users". Ten percent of the text pertains to actions or tasks carried out when using the devices. Regarding technology use, problematic use and addiction, $6 \%$ of references were coded in this category. The weighting of indicators for the different dimensions (personal, social, family, education, occupational or work) is between $8 \%$ and $12 \%$. Seven percent of the coded text is classified in the category "Profile of technology use in prevention programmes" and $8 \%$ in the "Family information required to specific the problem". Furthermore, the two categories with the lowest percentage weighting are related with family attitude, at $2 \%$, and other information required to define the problem, at $4 \%$ of the coded references.

The instrument derived from this first stage is made up of a total of 10 analytical dimensions, 46 assessment elements, and 122 items. It is accompanied by a first round of elements not accounted for, the purpose of which is to identify the person providing information, and one last question about final observations referring to the tool.

Differentiation between elements and items stems from the fact that the evaluation elements are understood as units of observation that configure each analytical dimension, and the items are analytical units established within the evaluation elements as scaled and compulsory multiple-choice items.

The instrument is applied by means of a personal interview between indicated prevention programme officers and the user offering the information.

\subsection{Stage 2: Results of the Procedure for Validating the Instruments by Means of Expert Opinion}

The end product of the previous stage had to be validated by means of a suitable methodological procedure. In this instance, expert opinion [34] was the chosen method because, rather than being 
expressed quantitatively using an index or coefficient, it is estimated by means of a generally subjective or intersubjective opinion given by experts in the field. The purpose of this technique is to collate the opinions of people whose academic or professional background reflects their capacity to give evidence or critical assessments of the object of study [35], which enhances the validity of the content studied by seeking rational consensus [36].

When setting up this group, the selection criteria used brought together academics and professionals from the field of drug addiction prevention, ICT specialists, as well as experts in the design of instruments. A total of 10 people took part in the expert panel, as shown in Table 2.

Table 2. Description of the group of experts.

\begin{tabular}{ccc}
\hline Number & Sex & Area of Work \\
\hline 1 & Woman & National Prevention Committee, Proyecto Hombre Association \\
2 & Woman & National Prevention Committee, Proyecto Hombre Association \\
3 & Woman & National Prevention Committee, Proyecto Hombre Association \\
4 & Man & Indicated Prevention Group (Proyecto Hombre Association) \\
5 & Woman & Indicated Prevention Group (Proyecto Hombre Association) \\
6 & Man & Indicated Prevention Group (Proyecto Hombre Association) \\
7 & Man & University of Salamanca \\
8 & Woman & Libertador Experimental Pedagogical University, Venezuela \\
9 & Woman & National Polytechnic Institute, Mexico \\
10 & Woman & National Plan on Drugs \\
\hline
\end{tabular}

According to Skjong and Wentworth and Escobar [37] and Cuervo [35], the analysis process involved e-mailing the group an invitation to complete a validation protocol for the two instruments generated in the previous stage. The procedure entailed evaluating each of the elements of the tool aimed at users, assigning a score between 1 and 5 ( 1 indicating the minimum score and 5 the maximum score), in accordance with the following criteria:

- Breadth of the content: fit of the question wording so that there is no redundancy and it is consistent with the response options.

- Congruency: linkage and coherence of the items that make up the instrument.

- Pertinence: correspondence between the content of the item and the dimension in which it will be used.

- Precision: rigorousness with which words have been used when formulating each item in order to express what said item aims to measure.

- Clarity: accuracy of the wording of each item, ensuring it is clear and easy to understand.

Once the ten experts had given their general opinion when validating the instrument designed to be used with young users of indicated prevention programmes, we observed that all the parameters defined had scored highly (see Table 3).

Table 3. General evaluation of the instrument designed for users.

\begin{tabular}{ccc}
\hline Evaluation Criteria & Mean & SD \\
\hline Breadth of content & 4.13 & 0.835 \\
Congruency & 4.13 & 0.641 \\
Pertinence & 4.14 & 0.690 \\
Precision & 3.88 & 0.641 \\
Clarity & 4.13 & 0.354 \\
\hline
\end{tabular}

A breakdown of the evaluation data for each of the elements that make up the instrument confirmed this result. Furthermore, the consensus obtained between the groups of expert judges was high according to Aiken's $V$ coefficient for the five stipulated criteria $(V>0.50)$ (see Table 4). 
Table 4. Evaluation of the elements of the instrument designed for users

\begin{tabular}{|c|c|c|c|c|c|c|c|c|c|c|c|c|c|c|c|}
\hline \multirow{2}{*}{ Element } & \multicolumn{3}{|c|}{ Breadth } & \multicolumn{3}{|c|}{ Congruence } & \multicolumn{3}{|c|}{ Pertinence } & \multicolumn{3}{|c|}{ Precision } & \multicolumn{3}{|c|}{ Clarity } \\
\hline & Mean & SD & $\mathbf{V}$ & Mean & SD & V & Mean & SD & $\mathbf{V}$ & Mean & SD & V & Mean & SD & V \\
\hline 1 & 3.67 & 1.581 & 0.733 & 3.89 & 1.269 & 0.911 & 3.89 & 1.054 & 0.911 & 3.56 & 1.333 & 0.711 & 4.11 & 1.054 & 0.800 \\
\hline 2 & 4.44 & 1.014 & 0.888 & 4.67 & 0.500 & 0.866 & 4.67 & 0.500 & 0.866 & 3.67 & 1.323 & 0.822 & 3.89 & 1.364 & 0.755 \\
\hline 3 & 4.44 & 0.527 & 0.888 & 4.56 & 0.527 & 0.866 & 4.56 & 0.527 & 0.911 & 4.67 & 0.500 & 0.577 & 4.56 & 0.527 & 0.822 \\
\hline 4 & 4.00 & 1.000 & 0.800 & 4.33 & 0.707 & 0.888 & 4.33 & 0.707 & 0.688 & 3.89 & 1.269 & 0.666 & 4.22 & 0.972 & 0.800 \\
\hline 5 & 4.56 & 1.014 & 0.911 & 4.33 & 1.118 & 0.733 & 4.33 & 1.000 & 0.711 & 3.56 & 1.590 & 0.777 & 3.89 & 1.364 & 0.755 \\
\hline 6 & 4.22 & 1.302 & 0.844 & 4.62 & 0.744 & & 4.75 & & & 4.25 & & & & 1.188 & \\
\hline 7 & 3.44 & 0.882 & 0.688 & 3.67 & 1.323 & & & 1.424 & & 2.89 & 1.453 & & & & \\
\hline 8 & 4.25 & 1.165 & 0.822 & 4.25 & 1.165 & 0.844 & 4.00 & 1.309 & 0.866 & 3.38 & 1.768 & 0.733 & 3.50 & 1.604 & 0.800 \\
\hline 9 & 4.00 & 1.323 & 0.800 & 4.22 & 0.972 & 0.844 & 4.33 & 1.000 & 0.866 & 3.89 & 1.054 & 0.711 & 3.44 & 1.333 & 0.755 \\
\hline 10 & 4.22 & 0.972 & 0.844 & 4.22 & 0.833 & 0.844 & 4.33 & 0.707 & 0.777 & 3.89 & 1.167 & 0.777 & 4.33 & 0.866 & 0.800 \\
\hline 11 & 4.11 & 1.269 & 0.822 & 4.22 & 1.302 & 0.755 & 4.33 & 1.000 & 0.866 & 4.00 & 1.000 & 0.755 & 4.44 & 0.527 & 0.800 \\
\hline 12 & 4.22 & 0.972 & 0.844 & 4.22 & 0.833 & 0.866 & 4.33 & 0.707 & 0.866 & 3.67 & 1.414 & 0.844 & 4.00 & 1.000 & 0.844 \\
\hline 13 & 3.78 & 1.302 & 0.755 & 3.78 & 1.302 & 0.866 & 3.89 & 1.269 & 0.822 & 3.56 & 1.236 & & & 0.991 & \\
\hline 14 & 4.33 & 1.000 & 0.866 & 4.33 & 1.000 & 0.8 & 4.33 & 0.866 & 0.822 & 3.89 & 1.453 & 0.844 & 4.00 & 1.500 & 0.933 \\
\hline 15 & 33 & 1.000 & 0.866 & 4.33 & 1.000 & 0.844 & 4.33 & 0.866 & 0.822 & 3.89 & 1.453 & 0.733 & 4.00 & 1.500 & 0.9 \\
\hline 16 & 4.22 & 1.302 & 0.844 & 4.22 & 1.302 & 0.844 & 4.11 & 1.364 & 0.822 & 3.78 & 1.641 & 0.8 & 4.00 & 1.500 & 0.822 \\
\hline 17 & 4.22 & 1.302 & 0.844 & 4.22 & 1.302 & 0.844 & 4.11 & 1.364 & 0.777 & 4.22 & 1.302 & 0.911 & & 1.302 & 0.777 \\
\hline 18 & 4.22 & 1.302 & 0.844 & 4.22 & 1.302 & 0.800 & 4.11 & 1.364 & 0.866 & 4.22 & 1.302 & 0.800 & 4.22 & 1.302 & 0.911 \\
\hline 19 & 4.22 & 1.302 & 0.844 & 4.22 & 1.302 & 0.822 & 4.11 & 1.364 & 0.822 & 4.22 & 1.302 & 0.577 & 4.22 & 1.302 & 0.844 \\
\hline 20 & 4.00 & 1.323 & 0.800 & 4.00 & 1.323 & 0.966 & 3.89 & 1.364 & 0.755 & 3.67 & 1.658 & 0.733 & 3.67 & 1.658 & 0.777 \\
\hline 21 & 4.33 & 0.707 & 0.866 & 4.25 & 0.707 & 0.800 & 4.33 & 0.707 & 0.777 & 4.50 & & 0.711 & 4.33 & 1.000 & \\
\hline 22 & & 0.726 & 0.888 & & & & & & & 4.56 & & & 4.3 & 1.000 & \\
\hline 23 & & 1.035 & 0.822 & & & & & & & & & & 3.7 & 1.488 & \\
\hline 24 & 4.00 & 1.225 & 0.800 & 3.67 & 1.581 & 0.822 & 3.89 & 1.453 & 0.911 & 2.89 & 1.453 & 0.911 & 3.33 & 1.323 & 0.688 \\
\hline 25 & 4.00 & 1.323 & 0.800 & 3.78 & 1.302 & 0.933 & 4.00 & 1.323 & 0.933 & 3.67 & 1.323 & 0.844 & 3.78 & 1.302 & 0.866 \\
\hline 26 & 4.00 & 1.323 & 0.800 & 4.43 & 0.787 & 0.933 & 4.00 & 1.323 & 0.888 & 3.56 & 1.424 & 0.777 & 3.67 & 1.323 & 0.888 \\
\hline 27 & 4.67 & 0.500 & 0.933 & 4.67 & 0.500 & 0.888 & 4.75 & 0.463 & 0.911 & 4.56 & 0.726 & 0.800 & 4.78 & 0.441 & 0.800 \\
\hline 28 & 4.88 & 0.354 & 0.933 & 4.88 & 0.354 & 0.866 & 4.88 & 0.354 & 0.844 & 4.88 & 0.354 & 0.755 & 4.75 & 0.463 & 0.755 \\
\hline 29 & & & 0.888 & 4.63 & & & 4.63 & & 0.822 & 4.75 & 0.463 & & 4.6 & 0.744 & 0.800 \\
\hline 30 & & 0.52 & 0.91 & & & & & & & & & & & 0.972 & \\
\hline 31 & 4.22 & 0.972 & 0.844 & 4.22 & 0.972 & 0.844 & 4.22 & 0.972 & 0.844 & 3.89 & 1.269 & 0.755 & 4.00 & 1.225 & 0.800 \\
\hline 32 & 4.11 & 1.054 & 0.844 & 4.11 & 1.054 & 0.844 & 4.11 & 1.054 & 0.866 & 4.00 & 1.323 & 0.911 & 3.78 & 1.481 & 0.844 \\
\hline 33 & 4.22 & 0.972 & 0.844 & 4.22 & 0.972 & 0.844 & 4.00 & 1.225 & 0.933 & 3.78 & 1.394 & 0.888 & 4.11 & 1.269 & 0.844 \\
\hline 34 & 4.22 & 1.093 & 0.844 & 4.22 & 1.093 & 0.800 & 4.22 & 1.093 & 0.911 & 4.11 & 1.364 & 0.800 & 4.00 & 1.323 & 0.844 \\
\hline 35 & 4.22 & 0.972 & 0.933 & 4.22 & 0.972 & 0.933 & 4.22 & 0.972 & 0.911 & 4.00 & 1.225 & 0.755 & 4.11 & 1.269 & 0.733 \\
\hline 36 & 4.22 & 1.093 & 0.911 & 4.00 & 1.118 & 0.911 & 4.50 & 0.756 & 0.911 & 3.78 & 1.302 & 0.800 & 3.67 & 1.225 & 0.866 \\
\hline 37 & 4.67 & 0.500 & 0.800 & 4.67 & 0.500 & & 4.67 & 0.500 & 0.922 & 4.56 & 0.527 & 0.800 & 4.56 & 0.726 & 0.866 \\
\hline 38 & 4.56 & & 0.822 & 4.56 & 0.726 & & & 0.726 & & 4.44 & 0.726 & & & 0.726 & 0.733 \\
\hline 39 & 4.13 & 0.835 & 0.844 & 4.33 & 0.707 & 0.844 & 4.56 & 0.527 & 0.888 & 4.00 & 0.707 & 0.844 & 4.11 & 0.928 & 0.666 \\
\hline 40 & 4.11 & 0.601 & 0.888 & 4.44 & 0.527 & 0.888 & 4.56 & 0.527 & 0.933 & 3.78 & 0.972 & 0.933 & 4.00 & 1.000 & 0.755 \\
\hline 41 & 4.22 & 0.833 & 0.888 & 4.22 & 0.833 & 0.911 & 4.25 & 1.035 & 0.955 & 4.13 & 0.991 & 0.933 & 4.00 & 0.926 & 0.733 \\
\hline 42 & 4.44 & 0.527 & 0.888 & 4.44 & 0.527 & 0.933 & 4.56 & 0.726 & 0.866 & 4.00 & 1.118 & 0.822 & 4.11 & 1.054 & 0.955 \\
\hline 43 & 4.44 & 0.527 & 0.955 & 4.56 & 0.726 & 0.955 & 4.44 & 1.014 & 0.711 & 4.22 & 0.972 & 0.777 & 4.00 & 1.000 & 0.911 \\
\hline 44 & 4.44 & 0.527 & 0.888 & 4.67 & 0.500 & 0.955 & 4.67 & 0.500 & 0.733 & 4.22 & 0.833 & 0.911 & 4.33 & 0.707 & 0.888 \\
\hline 45 & 4.78 & 0.441 & 0.777 & 4.78 & 0.441 & 0.777 & 4.78 & 0.441 & 0.933 & 4.67 & 0.500 & 0.844 & 4.56 & 0.527 & 0.844 \\
\hline 46 & 4.44 & 1.014 & 0.933 & 4.78 & 0.441 & 0.933 & 4.33 & 1.323 & 0.777 & 4.67 & 0.500 & 0.777 & 4.67 & 0.500 & 0.800 \\
\hline
\end{tabular}

The output from this second stage was a tool comprising the 10 analytical dimensions from the first draft, increasing the evaluation elements to 50 and the number of items to 138. It is accompanied by a first round of elements not previously taken into consideration, the purpose of which is to identify the user who is providing information, and one final question relating to final observations about the tool.

\subsection{Stage 3: Experimental Application of the Instrument to a Pilot Group}

Having incorporated the recommendations of the experts to create the second draft of the instrument, the next stage of definitive construction was the experimental application to a pilot group 
of users participating in indicated prevention programmes run by Proyecto Hombre. The aim of this pilot test was to evaluate the consistency of the instrument (properties of the scale and its constituent elements) and its appropriateness to the object of measurement.

To study the psychometric properties of the instrument, the following analytical procedures were applied to the dimensions that, in their wording, incorporate elements configured by items from the scaled evaluation (the dimensions Description of family sphere and Availability of digital devices in the home are made up of elements of choice and are not eligible for validation):

- Internal Consistency Analysis, in the sense of endowing the items with significance, in other words, ensuring that each of them measures a portion of the trait or characteristic studied. To this end, Cronbach's Alpha coefficient was used [38].

- Analysis of the discrimination capacity of the elements to reinforce the one-dimensional nature of the test. Student's $t$-test was applied to the mean values of the established groups, indication of validity endorsed by García, Gil y Rodríguez [39].

The 30 people chosen for the pilot study are taking part in indicated prevention programmes at six centres run by Proyecto Hombre (Asturias, Catalonia, Madrid, Malaga, Melilla and Murcia) in a similar proportion in each of them $(17.7 \%) .86 .7 \%$ are male, and the remaining $13.3 \%$ are female. The age of the participants ranged from 14 to 22, and the majority of them had completed secondary education $(73.3 \%)$. This number of people is valid to carry out this phase of the study according to McMillan and Schumacher [40].

Looking at the evaluation of the elements in the "Personal sphere" dimension, we see that the total value for Cronbach's Alpha in the scale (0.505) represents an acceptable correlation [41], an acceptable level of stability in the responses; hence, this part of the instrument presents signs of guaranteed reliability.

The discriminatory power of all the items in the test reinforces its one-dimensionality. To carry out this procedure, three closed items were chosen with ordinal response choices (response scale from 1 to 5) so that the sum total was recoded into three groups (Low, Medium and High):

1 = Low group (minimum value, percentile 33$):(6,16)$

2 = Medium group (percentile 34, percentile 66): $(17,23)$

$3=$ High group (percentile 67 , maximum value): $(24,35)$

By applying Student's $t$-test for independent samples, we were able to establish the existence or non-existence of statistical difference (n.s. $=0.05$ ) between the groups that score low and high in the selected elements. The results obtained using this test based on the 6 items belonging to this dimension and present in Table 5 show that $67 \%$ of the element possesses acceptable statistical discriminatory power, which indicates acceptable levels of validity in this dimension. The nondiscriminatory elements were maintained on account of their relevance in the instrument and in accordance with the suggestions made by the programme officers.

Table 5. Discriminatory power of the items in the dimension 'description of the personal sphere'.

\begin{tabular}{|c|c|c|c|c|c|}
\hline Items & $\begin{array}{l}\text { Lower } \\
\text { Mean }\end{array}$ & $\begin{array}{l}\text { Upper } \\
\text { Mean }\end{array}$ & $\mathbf{t}$ & $\mathbf{p}$ & Discriminatory? \\
\hline I feel frustrated when I have limitations with technology & 2.90 & 5.63 & -2.203 & 0.043 & Yes \\
\hline I lie about the actual amount of time I spend on technology & 1.70 & 4.13 & -2.362 & 0.031 & Yes \\
\hline I prefer to interact with others through technology & 2.40 & 3.63 & -1.487 & 0.157 & No \\
\hline I escape reality through the use of technology & 1.90 & 6.13 & -1.487 & 0.157 & No \\
\hline I seek refuge in technology because I feel alone & 1.30 & 3.63 & -4.581 & 0.001 & Yes \\
\hline I can't control the use of technology in my everyday life & 2.50 & 6.25 & -3.676 & 0.002 & Yes \\
\hline
\end{tabular}

The second dimension analysed, "ICT consumption habits", presented a low level of reliability, reflected in Cronbach's alpha coefficient, 0.27. Furthermore, discriminatory power revealed that 
only $25 \%$ of items have a valid discriminatory power (see Table 6 ). These results concluded that the dimension lacked acceptable reliability and validity criteria, and so we followed the recommendations of the prevention programme officers, by eliminating elements without discriminatory power and incorporating 13 new elements that would ensure the clarity and pertinence of the elements in the dimension according to the characteristics of the target population.

Table 6. Discriminatory power of the items in the dimension 'Information and Communication Technologies consumption habits'.

\begin{tabular}{lccccc}
\hline \multicolumn{1}{c}{ Items } & $\begin{array}{c}\text { Lower } \\
\text { Mean }\end{array}$ & $\begin{array}{c}\text { Upper } \\
\text { Mean }\end{array}$ & $\mathbf{t}$ & $\mathbf{p}$ & Discriminatory? \\
\hline $\begin{array}{l}\text { User's tendency to watch broadcast channels and } \\
\text { participate in comments }\end{array}$ & 2.00 & 5.00 & -2.183 & 0.049 & Yes \\
User's tendency to have a broadcast channel or to upload & 2.90 & 3.00 & -0.060 & 0.953 & No \\
random videos onto the Web & & & & & \\
User's tendency to participate in or look at Social Media & 6.00 & 8.11 & -1.767 & 0.095 & No \\
User's tendency to participate in instant messaging & 8.20 & 7.44 & 0.459 & 0.652 & No \\
User's tendency to play online through a video console & 3.80 & 5.78 & -1.277 & 0.219 & No \\
User's tendency to play online through other devices & 3.10 & 6.44 & -2.149 & 0.046 & Yes \\
User's tendency to watch series and film channels & 5.70 & 7.67 & -1.422 & 0.173 & No \\
User's tendency to look for information on the Net & 5.80 & 7.89 & -1.641 & 0.119 & No \\
User's tendency to listen to music on the Net & 7.80 & 9.33 & -1.291 & 0.214 & No \\
User's tendency to gamble online & 1.00 & 2.44 & -1.386 & 0.203 & No \\
User's tendency to shop online & 1.50 & 3.78 & -2.109 & 0.062 & No \\
User's tendency to consume sexual content online & 1.50 & 5.11 & -2.658 & 0.023 & Yes \\
\hline
\end{tabular}

Analysis of the 14 scaled items of the dimension "User's reasons for consuming ICT" revealed a guarantee of stability in the measure they offer, reflected in the Cronbach Alpha coefficient of 0.58. The application of the item discrimination test provided data that supported the observations proposed by the prevention programme officers participating in the study, since only $43 \%$ of items offered acceptable validity (see Table 7). The relevance of the contents processed did not lead to the suppression of any element but did lead to a redrafting of items where the discrimination was confusing.

Table 7. Discriminatory power of the items in the dimension 'Reasons for consuming Information and Communication Technologies'.

\begin{tabular}{lccccc}
\hline \multicolumn{1}{c}{ Items } & Lower Mean & Upper Mean & t & p & Discriminatory? \\
\hline Meeting new people & 4.78 & 7.00 & -1.785 & 0.093 & No \\
Contacting acquaintances & 7.11 & 8.89 & -1.985 & 0.065 & No \\
Family means of communication & 3.22 & 7.88 & -3.008 & 0.008 & Yes \\
Setting up groups according to context & 4.78 & 9.11 & -3.706 & 0.002 & Yes \\
Searching for information & 2.78 & 6.78 & -3.034 & 0.011 & Yes \\
Disconnecting & 2.67 & 4.00 & 0.393 & 0.393 & No \\
Technological update & 7.11 & 7.00 & 0.096 & 0.925 & No \\
Immediate satisfaction & 5.56 & 4.56 & 0.716 & 0.484 & No \\
Personal recognition & 3.00 & 6.67 & -2.750 & 0.014 & Yes \\
Repeat behaviours & 2.22 & 5.56 & -2.375 & 0.030 & Yes \\
Social pressure & 3.44 & 3.33 & 0.092 & 0.928 & No \\
Escaping from reality & 1.56 & 3.00 & -1.729 & 0.103 \\
Rebelling against authority & 2.11 & 5.11 & -2.252 & 0.044 & No \\
Other option & 2.67 & 3.67 & -0.986 & 0.339 \\
\hline
\end{tabular}

A Cronbach Alpha coefficient of 0.828 guaranteed the reliability of the 10 elements that make up the dimension "User's emotional management". Furthermore, the analytical test to establish the validity of these questions indicated that $70 \%$ offered valid content, leading us to revise the wording of three items (see Table 8). 
Table 8. Discriminatory power of the items in the dimension 'Emotional management'.

\begin{tabular}{|c|c|c|c|c|c|}
\hline Items & $\begin{array}{l}\text { Lower } \\
\text { Mean }\end{array}$ & $\begin{array}{l}\text { Upper } \\
\text { Mean }\end{array}$ & $\mathbf{t}$ & p & Discriminatory? \\
\hline Use of technology due to a feeling of dissatisfaction with interpersonal relations & 1.22 & 2.88 & -1.917 & 0.092 & No \\
\hline Use of technology because they help to relate with others & 2.33 & 7.00 & -5.484 & 0.000 & Yes \\
\hline Use of technology due to fear of facing reality & 1.33 & 2.88 & -1.872 & 0.097 & No \\
\hline Use of technology due to fear of being socially excluded & 1.11 & 2.25 & -1.551 & 0.163 & No \\
\hline Use of technology as a means of coping with shyness & 1.44 & 3.88 & -2.477 & 0.032 & Yes \\
\hline Use of technology due to fear of not being up to date & 1.00 & 3.25 & -1.865 & 0.046 & Yes \\
\hline Irritability over control over number of hours of technology use & 1.89 & 9.00 & -7.794 & 0.000 & Yes \\
\hline Displays of aggression when number of hours of technology use are controlled & 1.11 & 7.00 & -9.688 & 0.000 & Yes \\
\hline Fear of being without devices & 1.67 & 7.25 & -7.081 & 0.000 & Yes \\
\hline Use of technology due to fear of losing control over what is happening around them & 1.33 & 5.0 & -3.254 & 0.012 & Yes \\
\hline
\end{tabular}

The reliability of the scaled items in the dimension "ICT in the family setting" when the subject is living in the family home is very high (Cronbach Alpha $=0.839$ ). Sixty percent of these items possess an acceptable discriminatory power, which validates their inclusion in the instrument (see Table 9). Four of these items required further work based on the suggestions of the programme officers, who suggested that they should not be removed from the instrument but instead the wording needed to be revised to make them more understandable.

Table 9. Discriminatory power of the items in the dimension 'Information and Communication Technologies in the family settings-Effects of the use of technologies on cohabitation'.

\begin{tabular}{cccccc}
\hline Items & $\begin{array}{c}\text { Lower } \\
\text { Mean }\end{array}$ & $\begin{array}{c}\text { Upper } \\
\text { Mean }\end{array}$ & $\mathbf{t}$ & $\mathbf{p}$ & Discriminatory? \\
\hline The user does not speak with their father/guardian & 1.25 & 3.71 & -2.353 & 0.052 & No \\
The user fights with their father/guardian & 1.00 & 4.86 & -3.911 & 0.008 & Yes \\
The user is aggressive and rude towards their father/guardian & 1.13 & 3.29 & -2.853 & 0.027 & Yes \\
The user does not speak with their mother/guardian & 1.25 & 6.00 & -2.803 & 0.030 & Yes \\
The user fights with their mother/guardian & 1.75 & 7.00 & -4.020 & 0.002 & Yes \\
The user is aggressive and rude towards their mother/guardian & 1.00 & 4.57 & -2.946 & 0.026 & Yes \\
The user does not speak with their sibling(s) & 1.25 & 4.00 & -1.832 & 0.114 & No \\
The user fights with their sibling(s) & 1.00 & 3.43 & -2.497 & 0.047 & Yes \\
The user is aggressive and rude towards their sibling(s) & 1.00 & 3.00 & -2.103 & 0.080 & No \\
The user does not participate in family activities & 1.25 & 4.57 & -2.265 & 0.062 & No \\
\hline
\end{tabular}

The eight elements that make up the dimension "ICT in the social setting", once the relevant reliability test had been applied, contributed a global value of 0.890 , clearly demonstrating their metric consistency. Furthermore, the application of the validity test showed that $100 \%$ of these items possess discriminatory power (see Table 10).

Table 10. Discriminatory power of the items in the dimension 'Information and Communication Technologies in the family settings-Effects of technology use on cohabitation'.

\begin{tabular}{|c|c|c|c|c|c|}
\hline Items & $\begin{array}{l}\text { Lower } \\
\text { Mean }\end{array}$ & $\begin{array}{l}\text { Upper } \\
\text { Mean }\end{array}$ & $\mathbf{t}$ & p & Discriminatory? \\
\hline The user shows more interest in virtual than physical relationships & 1.17 & 2.60 & -3.523 & 0.004 & Yes \\
\hline The user enjoys virtual relations more than physical relationships & 1.00 & 3.50 & -2.748 & 0.023 & Yes \\
\hline The user shows their emotions more easily in the virtual world than in the physical world & 1.42 & 6.00 & -5.144 & 0.000 & Yes \\
\hline The user says what they think more easily in the virtual world than in the physical world & 1.92 & 5.90 & -3.584 & 0.004 & Yes \\
\hline The user pays more attention to virtual conversations than ones in the physical world & 1.25 & 4.80 & -4.260 & 0.002 & Yes \\
\hline
\end{tabular}


The internal consistency of the nine scaled elements that describe the dimension "ICT in the education setting" was 0.880 , scientifically guaranteeing their reliability. The validity of these items, measured by means of the corresponding item discriminatory test, showed that $89 \%$ measure the construct covered by this dimension, with just one of the items requiring revision. Furthermore, it should be noted that, at the request of the programme officers, a new element was incorporated into this dimension on account of its relevance for the subject studied (see Table 11).

Table 11. Discriminatory power of the items in the dimension 'Information and Communication Technologies in the family settings-Effects of technology in the education setting'.

\begin{tabular}{cccccc}
\hline Items & $\begin{array}{c}\text { Lower } \\
\text { Mean }\end{array}$ & $\begin{array}{c}\text { Upper } \\
\text { Mean }\end{array}$ & $\mathbf{t}$ & $\mathbf{p}$ & Discriminatory? \\
\hline $\begin{array}{c}\text { Breaks school rules regarding the use of technology and } \\
\text { has on occasion been told off because of this }\end{array}$ & 3.57 & 6.67 & -1.950 & 0.075 & No \\
Grades have gone down & 1.00 & 5.14 & -3.023 & 0.023 & Yes \\
Finds it harder to concentrate on studies & 2.57 & 7.71 & -4.129 & 0.001 & Yes \\
Finds it hard to pay attention in class & 1.71 & 6.43 & -3.200 & 0.008 & Yes \\
Finds it hard to memorise concepts & 1.00 & 5.86 & -4.250 & 0.005 & Yes \\
Doesn't do homework & 1.86 & 7.57 & -6.124 & 0.000 & Yes \\
Skips class & 1.14 & 4.29 & -2.465 & 0.048 & Yes \\
Doesn't want to study anymore & 1.00 & 5.43 & -3.175 & 0.019 & Yes \\
Doesn't interact with classmates & 1.29 & 4.86 & -2.933 & 0.013 & Yes \\
\hline
\end{tabular}

Finally, the eight elements that make up the dimension "ICT in the work setting" possess a high degree of reliability, as reflected in the Cronbach Alpha coefficient, 0.769 , although in contrast these are not items that possess an acceptable level of discriminatory power, and accordingly all of them needed to be revised (see Table 12). However, it should be noted that only $5 \%$ of these prevention programmes participants are engaged in the employment market; hence, the results obtained understandable. Accordingly, the decision was made to maintain the elements as originally formulated.

Table 12. Discriminatory power of the items in the dimension 'Information and Communication Technologies in the work setting'.

\begin{tabular}{|c|c|c|c|c|c|}
\hline Items & $\begin{array}{l}\text { Lower } \\
\text { Mean }\end{array}$ & $\begin{array}{l}\text { Upper } \\
\text { Mean }\end{array}$ & $\mathbf{t}$ & $\mathbf{p}$ & Discriminatory? \\
\hline Skips work & 1.00 & 1.50 & -1.633 & 0.178 & No \\
\hline Stops doing job/can't manage to do what they are supposed to & 1.00 & 1.50 & -1.633 & 0.178 & No \\
\hline Arrives at work late & 1.00 & 4.00 & -1.500 & 0.374 & No \\
\hline Is tired & 1.00 & 8.00 & -1.000 & 0.500 & No \\
\hline Has conflicts with colleagues & 1.00 & 4.00 & -1.500 & 0.374 & No \\
\hline Has conflicts with boss(es) & 1.00 & 4.00 & -1.500 & 0.374 & No \\
\hline Has had a workplace accident & 1.00 & 1.50 & -1.633 & 0.178 & No \\
\hline Doesn't want to go to work & 1.00 & 6.00 & -1.250 & 0.430 & No \\
\hline
\end{tabular}

Following the same analytical dynamic as in the previous stages, the result of this third stage was a tool in the format of a personalised interview administered by prevention programme officers, made up of 10 analytical dimensions, 50 evaluation elements, and 156 items (see Table 13). As indicated previously, it is supplemented by a first round of elements, the purpose of which is to identify the user who is providing the information, along with an observations section in each dimension, and one final question related to final observations about the tool, all of which are not included in the total number of elements that make up in the final instrument (see Appendix A). 
Table 13. Description of the definitive instrument aimed at programme users.

\begin{tabular}{lcccccc}
\hline \multicolumn{1}{c}{ Dimension } & \multicolumn{2}{c}{ Draft 1 } & \multicolumn{2}{c}{ Draft 2 } & \multicolumn{2}{c}{ Draft 3 } \\
& Elements & Items & Elements & Items & Elements & Items \\
\hline 1. Description of personal sphere & 9 & 14 & 9 & 14 & 9 & 25 \\
2. Description of family sphere & 17 & 17 & 17 & 17 & 17 & 17 \\
3. Availability of digital devices in the home & 1 & 1 & 1 & 1 & 1 & 1 \\
4. ICT consumption habits & 12 & 22 & 12 & 23 & 12 & 30 \\
5. Reasons for consuming ICT & 1 & 16 & 3 & 18 & 3 & 17 \\
6. Description of emotional management & 1 & 10 & 1 & 10 & 1 & 10 \\
7. ICT in the family setting & 2 & 16 & 4 & 30 & 4 & 30 \\
8. ICT in the social setting & 1 & 9 & 1 & 8 & 1 & 8 \\
9. ICT in the education setting & 1 & 8 & 1 & 9 & 1 & 10 \\
10. ICT in the work setting & 1 & 9 & 1 & 8 & 1 & 8 \\
\hline Total & 46 & 122 & 50 & 138 & 50 & 156 \\
\hline
\end{tabular}

\section{Discussion}

Following the results set out regarding the construction and validation of the instrument created to identify technology use, abuse or addiction among the young people taking part in indicated prevention programmes run by the Proyecto Hombre Association throughout Spain, we can confirm that the instrument fulfills the parameters established to be classed as a systematic and empirically sustainable instrument, since the youth population needs to identify these patterns in order to understand and prevent risk behaviours associated with technology usage. In turn, the instrument must differentiate between the applications used and the use being made of them, in order to understand whether minors are using or abusing them [25]. This instrument adds to the contributions of López-Fenández, Freixa-Blanxart and Honrubia-Serrano's internet abuse scale for adolescents [27], detailing the devices used, the habits and reasons for consumption and the effects of use in the family, professional and emotional dimensions. There are direct connections to the instrument designed by Chen, Ho and Lwin [24] in the emotional and social effects, but the possible situations of bullying that arise with the use of these devices are not specified. Also, the scale designed by Peris, Maganto and Garaigordobil [42], focused on the use of social networks, prioritizes elements that are worked on in the instrument designed here such as the social use of devices and nomophobia.

The Jiménez, Alvarado and Llopis [43] instrument assesses the usefulness of ICT in the work of university students, the emotions that their use generates and the feelings of frustration that their absence generates. Understood by these elements as predictors of ICT addiction, the instrument referred to in this article considers those aspects in the adolescent population participating in the indicated prevention programmes. More than $28 \%$ of university students display risk behaviours with regard to the use of technology, and other variables need to be taken into consideration such as personality, family setting, and peer group [44]. The study conducted by [45] establishes that $90.6 \%$ of the population engages in controlled use of the internet, and just $9.4 \%$ have frequent problems.

However, the specificity of the adolescents attended in the indicated prevention programs for drug use and other risky behaviors and their relationship to the problematic use of ICT [46] and other behavioral problems or mismanagement of impulsivity [47] make it necessary to create an instrument adapted to new casuistic. Hence, this instrument facilitates the identification of use, abuse, and addiction profiles and their relationship with the technologies associated with these patterns.

\section{Conclusions}

By means of a mixed, nonsequential experimental study, three stages were developed with a view to achieving the aim of this research.

First, conducting semi-structured interviews with 15 programme officers working at Proyecto Hombre has shed light on risk factors in the family, education, and social dimensions, which can lead to problematic or addictive behaviour with regard to technological devices. This information was 
used to consolidate an initial draft of the evaluation instrument, comprising a total of 10 analytical dimensions, 46 evaluation elements, and 122 items.

Then, a panel of 10 experts in the evaluation of technology use, abuse, and addiction took part in the project. The results of the consensus analysis conducted allowed us to reshape the instrument into 10 analytical dimensions, 50 evaluation elements, and 138 items.

The third stage in the design of this tool involved the experimental application of this instrument to a pilot group of 30 users. The aim of this stage was to identify the reliability and validity indices of the instrument. Analysis of the information provided in this stage gave rise to the definitive instrument, made up of 10 analytical dimensions, 50 evaluation elements and 156 items. These dimensions are: description of the personal sphere, description of the family sphere, availability of digital devices in the home, ITC consumption habits, reasons for consuming ICT, description of emotional management, ICT in the family setting, ICT in the social setting, ICT in the education setting, and ICT in the work setting. The instrument was applied by means of a personalised interview conducted by prevention programme officers with users of the programme who provided the information.

Author Contributions: Conceptualization, E.R.U., J.A.F.E. and G.M.-S.; formal analysis, I.G.L., B.Q.O. and E.R.U.; methodology, B.Q.O.; project administration, I.G.L.; validation, B.Q.O. and E.R.U.; writing—original draft, I.G.L. and G.M.-S.; writing-review \& editing, I.G.L. and J.A.F.E. All authors have read and agreed to the published version of the manuscript.

Funding: This research was funded by Fundación Bancaria "La Caixa" and Proyecto Hombre Association.

Conflicts of Interest: The authors declare no conflicts of interest. The funders had no role in the design of the study; in the collection, analyses, or interpretation of data; in the writing of the manuscript, or in the decision to publish the results.

\section{Appendix A}

Evaluation tool for problems of use, abuse or addiction of ICT

Property of Proyecto Hombre Association

\section{PERSONAL SPHERE DESCRIPTION}

1. What is the reason or reasons that led you to attend the youth program?

2. Point out how much time you spend on leisure per day: _ Less than 1 hour $\_1$ or 2 hours _ 3 or 4 hours _ 5 or 6 hours _ More than 6 hours

3. Value from 0 to $10(0=$ nothing and $10=$ much $)$ the accomplishment you do of the following activities:

\begin{tabular}{|l|c|c|c|c|c|c|c|c|c|c|c|}
\hline Practice some sport & 0 & 1 & 2 & 3 & 4 & 5 & 6 & 7 & 8 & 9 & 10 \\
\hline Going to the movies & 0 & 1 & 2 & 3 & 4 & 5 & 6 & 7 & 8 & 9 & 10 \\
\hline Volunteering & 0 & 1 & 2 & 3 & 4 & 5 & 6 & 7 & 8 & 9 & 10 \\
\hline Going out with friends & 0 & 1 & 2 & 3 & 4 & 5 & 6 & 7 & 8 & 9 & 10 \\
\hline Watching TV & 0 & 1 & 2 & 3 & 4 & 5 & 6 & 7 & 8 & 9 & 10 \\
\hline Listening to music & 0 & 1 & 2 & 3 & 4 & 5 & 6 & 7 & 8 & 9 & 10 \\
\hline Reading & 0 & 1 & 2 & 3 & 4 & 5 & 6 & 7 & 8 & 9 & 10 \\
\hline Play on the computer, tablet or video console & 0 & 1 & 2 & 3 & 4 & 5 & 6 & 7 & 8 & 9 & 10 \\
\hline Surf the Net & 0 & 1 & 2 & 3 & 4 & 5 & 6 & 7 & 8 & 9 & 10 \\
\hline Use the social media & 0 & 1 & 2 & 3 & 4 & 5 & 6 & 7 & 8 & 9 & 10 \\
\hline Chat in Instant Messaging & 0 & 1 & 2 & 3 & 4 & 5 & 6 & 7 & 8 & 9 & 10 \\
\hline Other option & 0 & 1 & 2 & 3 & 4 & 5 & 6 & 7 & 8 & 9 & 10 \\
\hline
\end{tabular}

4. How do you like doing the activities in your leisure time? Mark three options according to your preferences, indicating them in $1^{\circ}, 2^{\circ}$ or $3^{\circ}\left(1^{\circ}=\right.$ highest priority at $3^{\circ}=$ lowest priority). _ Alone _ With friends _ With classmates _ With the whole family _ With my father/mother/tutor _ With my siblings _ With my partner _ With my children

5. Do you consume any kind of drugs? _ Yes _ No 
6. If yes, please indicate which one:

7. Have you attended or attend any other programs or received any therapy? _ Yes _ No

8. If yes, please indicate which one:

9. Indicate to what extent you identify yourself with the following statements $(0=$ nothing and $10=$ much):

\begin{tabular}{|l|l|l|l|l|l|l|l|l|l|l|l|}
\hline I feel frustrated when I have limitations with technology & 0 & 1 & 2 & 3 & 4 & 5 & 6 & 7 & 8 & 9 & 10 \\
\hline I lie about the actual amount of time I spend on technology & 0 & 1 & 2 & 3 & 4 & 5 & 6 & 7 & 8 & 9 & 10 \\
\hline I prefer to interact with others through technology & 0 & 1 & 2 & 3 & 4 & 5 & 6 & 7 & 8 & 9 & 10 \\
\hline I escape reality through the use of technology & 0 & 1 & 2 & 3 & 4 & 5 & 6 & 7 & 8 & 9 & 10 \\
\hline I seek refuge in technology because I feel alone & 0 & 1 & 2 & 3 & 4 & 5 & 6 & 7 & 8 & 9 & 10 \\
\hline I can't control the use of technology in my everyday life & 0 & 1 & 2 & 3 & 4 & 5 & 6 & 7 & 8 & 9 & 10 \\
\hline
\end{tabular}

\section{DESCRIPTION OF FAMILY SPHERE}

10. What is your usual place of residence? _ The family home _ A rented apartment _ A children's centre _ A major school or residence _ An owned flat _ Another, indicate which one:

11. Who do you live with at your usual residence? _ Father/tutor _ Mother/tutor _ siblings _ Grandparents _ Teachers _ Friends _ Classmates _ Partner _ Sons _ Others, indicate which one:

\section{In case of living in the family home}

12. What is the marital status of your parents? (In the case of reconstructed families, note the situation of the father and the mother in the 12th bis). _ Married _ Domestic couple _ Separated _ _ Divorced _ Widower _ Other, indicate which one:

12 In the case of reconstructed families, indicate the situation of the mother. _Married _ Domestic

bis. partner _ Separated _ Divorced _ Widow _ Other, indicate which one:

13. Regarding communication, how is the relationship between them? _ None/Very bad _ Little/Bad _ Good _ Very Good __ Don't know, don't answer

\section{In case of living with your partner}

12. What is the link with it? _ Married _ Domestic couple _ Separated _ Divorced

13. Regarding communication, how is the relationship with your partner? _ None/Very bad _ Little/Bad _ Good _ Very Good _ Don't know, don't answer

\section{In the case of living with classmates or Friends}

13. How is your communication with them? _ None/Very bad _ Little/Bad _ Good _ Very Good _ Don't know, don't answer

14. What studies does your father/tutor have?

15. What does your father/tutor (profession) do?

16. What studies does your mother/tutor have?

17. What does your mother/tutor do?

18. What studies does your partner have?

19. What does your partner do?

\section{In case of having children}

20. How many do you have?

21. How old are they? 
20. How many siblings do you have?

21. If you have any siblings, what place do you occupy among them?

22. If you have any siblings, how old are they?

23. What do your brothers do? Study, how many of them? Work, how many of them? Unemployed, how many of them? Unemployed and do nothing, how many of them?

24. What is your relationship with your family members? (communication, coexistence, etc.) _ None _ Little__ Good _ Very Good

In case of living in the family home

25. What does your father/mother/tutor say about your use of technologies?

\section{In case of living with your partner}

25. What does he/she tell you about your use of technologies?

26. Based on what you said in the previous question, what do you think about it?

\section{AVAILABILITY OF DIGITAL DEVICES AT HOME}

27. Indicate which digital devices do you have in your usual residence: _ Mobile phone _ Video console _ Television Smart-TV _ Smartwatch

\section{ICT CONSUMPTION HABITS}

28. Indicate how much time you spend each day using technology: _ Less than 1 hour _ 1 or 2 hours _ 3 or 4 hours _ 5 or 6 hours _ More than 6 hours

29. Indicate which type of devices you use the most $(0=$ nothing and $10=$ much):

\begin{tabular}{|l|l|l|l|l|l|l|l|l|l|l|l|}
\hline Mobile phone & 0 & 1 & 2 & 3 & 4 & 5 & 6 & 7 & 8 & 9 & 10 \\
\hline Video console & 0 & 1 & 2 & 3 & 4 & 5 & 6 & 7 & 8 & 9 & 10 \\
\hline Computer & 0 & 1 & 2 & 3 & 4 & 5 & 6 & 7 & 8 & 9 & 10 \\
\hline Tablet & 0 & 1 & 2 & 3 & 4 & 5 & 6 & 7 & 8 & 9 & 10 \\
\hline Television Smart-TV & 0 & 1 & 2 & 3 & 4 & 5 & 6 & 7 & 8 & 9 & 10 \\
\hline Smartwatch & 0 & 1 & 2 & 3 & 4 & 5 & 6 & 7 & 8 & 9 & 10 \\
\hline Ebook & 0 & 1 & 2 & 3 & 4 & 5 & 6 & 7 & 8 & 9 & 10 \\
\hline Other option & 0 & 1 & 2 & 3 & 4 & 5 & 6 & 7 & 8 & 9 & 10 \\
\hline
\end{tabular}

30. Who do you like to use technologies with? Mark three options according to your preferences, indicating them in $1^{\circ}, 2^{\circ}$ or $3^{\circ}\left(1^{\circ}=\right.$ highest priority at $3^{\circ}=$ lowest priority). _ Alone _ With friends _ With classmates _ With the whole family _ With my father/mother/tutor _ With my siblings _ With my partner _ With my children

31. When you are using technologies, do you remember to eat (breakfast, lunch or dinner)? _I don't remember__ Sometimes I remember__ Yes, I remember

32. In case of choosing options one and/or two (I don't remember, sometimes I remember), why do you think you forget?

33. When you are using technologies, do you remember to clean yourself (shower, brush your teeth, comb your hair, etc.) _ I I don't remember _ Sometimes I remember _ Yes, I remember

34. In case of choosing options one and/or two (I don't remember, sometimes I remember), why do you think you forget? 
35. When you are using technologies, do you remember stopping to do some physical activity? _ I don't remember _ Sometimes I remember _ Yes, I remember

36. In case of choosing options one and/or two (I don't remember, sometimes I remember), why do you think you forget?

37. When you are using technologies, do you keep the rest hours (sleep the recommended hours)? _ I I don't remember _ Sometimes I remember _ Yes, I remember

38. In case of choosing options one and/or two (I don't remember, sometimes I remember), why do you think you forget?

39. Rate from 0 to $10(0=$ nothing and $10=$ much $)$ to what extent you perform the following activities:

\begin{tabular}{|l|l|l|l|l|l|l|l|l|l|l|l|}
\hline Watching broadcast channels and participating in comments & 0 & 1 & 2 & 3 & 4 & 5 & 6 & 7 & 8 & 9 & 10 \\
\hline $\begin{array}{l}\text { Having a broadcast channel or uploading random videos } \\
\text { onto the Web }\end{array}$ & 0 & 1 & 2 & 3 & 4 & 5 & 6 & 7 & 8 & 9 & 10 \\
\hline Participating in or looking at Social Media & 0 & 1 & 2 & 3 & 4 & 5 & 6 & 7 & 8 & 9 & 10 \\
\hline Participating in instant messaging & 0 & 1 & 2 & 3 & 4 & 5 & 6 & 7 & 8 & 9 & 10 \\
\hline Playing online through a video console & 0 & 1 & 2 & 3 & 4 & 5 & 6 & 7 & 8 & 9 & 10 \\
\hline Playing online through other devices & 0 & 1 & 2 & 3 & 4 & 5 & 6 & 7 & 8 & 9 & 10 \\
\hline Watching series and film channels & 0 & 1 & 2 & 3 & 4 & 5 & 6 & 7 & 8 & 9 & 10 \\
\hline Looking for information on the Net & 0 & 1 & 2 & 3 & 4 & 5 & 6 & 7 & 8 & 9 & 10 \\
\hline Listening to music on the Net & 0 & 1 & 2 & 3 & 4 & 5 & 6 & 7 & 8 & 9 & 10 \\
\hline Gambling online & 0 & 1 & 2 & 3 & 4 & 5 & 6 & 7 & 8 & 9 & 10 \\
\hline Shopping online & 0 & 1 & 2 & 3 & 4 & 5 & 6 & 7 & 8 & 9 & 10 \\
\hline Consuming sexual content online & 0 & 1 & 2 & 3 & 4 & 5 & 6 & 7 & 8 & 9 & 10 \\
\hline Other option & 0 & 1 & 2 & 3 & 4 & 5 & 6 & 7 & 8 & 9 & 10 \\
\hline
\end{tabular}

REASONS FOR CONSUMING ICT

40. Value from 0 to $10(0=$ nothing and $10=$ much $)$ each of the following reasons of using technologies:

\begin{tabular}{|l|l|l|l|l|l|l|l|l|l|l|l|}
\hline Meeting new people & 0 & 1 & 2 & 3 & 4 & 5 & 6 & 7 & 8 & 9 & 10 \\
\hline Contacting acquaintances & 0 & 1 & 2 & 3 & 4 & 5 & 6 & 7 & 8 & 9 & 10 \\
\hline Family means of communication & 0 & 1 & 2 & 3 & 4 & 5 & 6 & 7 & 8 & 9 & 10 \\
\hline Setting up groups according to context & 0 & 1 & 2 & 3 & 4 & 5 & 6 & 7 & 8 & 9 & 10 \\
\hline Searching for information & 0 & 1 & 2 & 3 & 4 & 5 & 6 & 7 & 8 & 9 & 10 \\
\hline Searching work offers & 0 & 1 & 2 & 3 & 4 & 5 & 6 & 7 & 8 & 9 & 10 \\
\hline Disconnecting & 0 & 1 & 2 & 3 & 4 & 5 & 6 & 7 & 8 & 9 & 10 \\
\hline Technological update & 0 & 1 & 2 & 3 & 4 & 5 & 6 & 7 & 8 & 9 & 10 \\
\hline Immediate satisfaction & 0 & 1 & 2 & 3 & 4 & 5 & 6 & 7 & 8 & 9 & 10 \\
\hline Personal recognition & 0 & 1 & 2 & 3 & 4 & 5 & 6 & 7 & 8 & 9 & 10 \\
\hline Repeating behaviours & 0 & 1 & 2 & 3 & 4 & 5 & 6 & 7 & 8 & 9 & 10 \\
\hline Social pressure & 0 & 1 & 2 & 3 & 4 & 5 & 6 & 7 & 8 & 9 & 10 \\
\hline Escaping from reality & 0 & 1 & 2 & 3 & 4 & 5 & 6 & 7 & 8 & 9 & 10 \\
\hline Rebelling against authority & 0 & 1 & 2 & 3 & 4 & 5 & 6 & 7 & 8 & 9 & 10 \\
\hline Other option & 0 & 1 & 2 & 3 & 4 & 5 & 6 & 7 & 8 & 9 & 10 \\
\hline
\end{tabular}

41. Do you use technologies for educational or work purposes? _ Yes _ No

42. If yes, indicate what you use them for

\section{DESCRIPTION OF EMOTIONAL MANAGEMENT}

43. Indicate to what extent you identify with each of the following statements $(0=$ nothing and $10=$ much): 


\begin{tabular}{|l|l|l|l|l|l|l|l|l|l|l|l|}
\hline $\begin{array}{l}\text { Using technology due to a feeling of dissatisfaction with the } \\
\text { relationship with my peer group }\end{array}$ & 0 & 1 & 2 & 3 & 4 & 5 & 6 & 7 & 8 & 9 & 10 \\
\hline Using technology because they help to relate with others & 0 & 1 & 2 & 3 & 4 & 5 & 6 & 7 & 8 & 9 & 10 \\
\hline Using technology due to fear of facing reality & 0 & 1 & 2 & 3 & 4 & 5 & 6 & 7 & 8 & 9 & 10 \\
\hline $\begin{array}{l}\text { Using technology due to fear of being excluded from my } \\
\text { peer group }\end{array}$ & 0 & 1 & 2 & 3 & 4 & 5 & 6 & 7 & 8 & 9 & 10 \\
\hline Using technology as a mean of coping with shyness & 0 & 1 & 2 & 3 & 4 & 5 & 6 & 7 & 8 & 9 & 10 \\
\hline Using technology due to fear of not being up to date & 0 & 1 & 2 & 3 & 4 & 5 & 6 & 7 & 8 & 9 & 10 \\
\hline $\begin{array}{l}\text { Irritability over control over number of hours of } \\
\text { technology use }\end{array}$ & 0 & 1 & 2 & 3 & 4 & 5 & 6 & 7 & 8 & 9 & 10 \\
\hline $\begin{array}{l}\text { Displays of aggression when number of hours of technology } \\
\text { use are controlled }\end{array}$ & 0 & 1 & 2 & 3 & 4 & 5 & 6 & 7 & 8 & 9 & 10 \\
\hline Fear of being without devices & 0 & 1 & 2 & 3 & 4 & 5 & 6 & 7 & 8 & 9 & 10 \\
\hline $\begin{array}{l}\text { Using technology due to fear of losing control over what is } \\
\text { happening around them }\end{array}$ & 0 & 1 & 2 & 3 & 4 & 5 & 6 & 7 & 8 & 9 & 10 \\
\hline
\end{tabular}

\section{ICT IN THE FAMILY SETTING}

44. Indicate how your father, tutor, or partner reacts to your time spent using technologies. Specify next to the chosen option(s) who adopts that attitude. _ He/She tells me to leave it or that it is not good, but in the end, he allows me (permissive): $\mathrm{He} / \mathrm{she}$ removes me the device or punishes me without it (authoritarian): $\mathrm{He} / \mathrm{She}$ tries to make me aware of the problem and lets me decide what to do (participatory): $\mathrm{He} / \mathrm{she}$ tells me nothing, although he/she knows it (passive): $\mathrm{He} / \mathrm{she}$ talks to me and tries to make me do other things (transformational): $\mathrm{He} / \mathrm{She}$ does not get involved because he/she knows you have nothing to do (user empowerment): He/she does not get involved because he/she does not know how to manage the use of the devices (unknown): - He/she does not tell me anything because I get irritated and I get violent (fear): $\mathrm{He} / \mathrm{she}$ uses it to reward achievement of goals (reward):

\section{In case of living in the family home}

45. Rate the extent to which the use of technologies affects coexistence $(0=$ nothing and $10=$ much):

\begin{tabular}{|l|l|l|l|l|l|l|l|l|l|l|l|}
\hline The user does not speak with his/her father/tutor & 0 & 1 & 2 & 3 & 4 & 5 & 6 & 7 & 8 & 9 & 10 \\
\cline { 2 - 8 } The user fights with his/her father/tutor & 0 & 1 & 2 & 3 & 4 & 5 & 6 & 7 & 8 & 9 & 10 \\
\cline { 2 - 9 } The user is aggressive and rude towards his/her father/tutor & 0 & 1 & 2 & 3 & 4 & 5 & 6 & 7 & 8 & 9 & 10 \\
\hline The user does not speak with his/her mother/tutor & 0 & 1 & 2 & 3 & 4 & 5 & 6 & 7 & 8 & 9 & 10 \\
\cline { 2 - 9 } The user fights with his/her mother/tutor & 0 & 1 & 2 & 3 & 4 & 5 & 6 & 7 & 8 & 9 & 10 \\
\cline { 2 - 9 } The user is aggressive and rude towards his/her mother/tutor & 0 & 1 & 2 & 3 & 4 & 5 & 6 & 7 & 8 & 9 & 10 \\
\hline The user does not speak with his/her sibling(s) & 0 & 1 & 2 & 3 & 4 & 5 & 6 & 7 & 8 & 9 & 10 \\
\cline { 2 - 9 } The user fights with his/her sibling(s) & 0 & 1 & 2 & 3 & 4 & 5 & 6 & 7 & 8 & 9 & 10 \\
\hline The user is aggressive and rude towards his/her sibling(s) & 0 & 1 & 2 & 3 & 4 & 5 & 6 & 7 & 8 & 9 & 10 \\
\cline { 2 - 10 } The user does not participate in family activities & 0 & 1 & 2 & 3 & 4 & 5 & 6 & 7 & 8 & 9 & 10 \\
\hline
\end{tabular}

\section{In case of living with the partner}

46. Rate the extent to which the use of technologies affects coexistence $(0=$ nothing and $10=$ much):

\begin{tabular}{|l|c|c|c|c|c|c|c|c|c|c|c|}
\hline I don't talk to my partner & 0 & 1 & 2 & 3 & 4 & 5 & 6 & 7 & 8 & 9 & 10 \\
\cline { 2 - 9 } I fight with my partner & 0 & 1 & 2 & 3 & 4 & 5 & 6 & 7 & 8 & 9 & 10 \\
\cline { 2 - 9 } I get aggressive and talk badly to my partner & 0 & 1 & 2 & 3 & 4 & 5 & 6 & 7 & 8 & 9 & 10 \\
\hline I don't talk to my kids & 0 & 1 & 2 & 3 & 4 & 5 & 6 & 7 & 8 & 9 & 10 \\
\cline { 2 - 10 } I fight with my children & 0 & 1 & 2 & 3 & 4 & 5 & 6 & 7 & 8 & 9 & 10 \\
\hline I become aggressive and speak badly to my children & 0 & 1 & 2 & 3 & 4 & 5 & 6 & 7 & 8 & 9 & 10 \\
\cline { 2 - 9 } The user does not participate in family activities & 0 & 1 & 2 & 3 & 4 & 5 & 6 & 7 & 8 & 9 & 10 \\
\hline
\end{tabular}

\section{In case of living with friends or classmates}


47. Rate the extent to which the use of technologies affects coexistence:

\begin{tabular}{|l|l|l|l|l|l|l|l|l|l|l|l|}
\hline I don't talk to them & 0 & 1 & 2 & 3 & 4 & 5 & 6 & 7 & 8 & 9 & 10 \\
\hline I fight with them & 0 & 1 & 2 & 3 & 4 & 5 & 6 & 7 & 8 & 9 & 10 \\
\hline I become aggressive and speak badly to them & 0 & 1 & 2 & 3 & 4 & 5 & 6 & 7 & 8 & 9 & 10 \\
\hline I don't participate in the activities that are organized & 0 & 1 & 2 & 3 & 4 & 5 & 6 & 7 & 8 & 9 & 10 \\
\hline
\end{tabular}

\section{ICT IN THE SOCIAL SETTING}

48. Regards the social sphere, rate to what extent the use of technologies affects your relationships, in each of the following statements $(0=$ nothing and $10=$ much $)$ :

\begin{tabular}{|l|l|l|l|l|l|l|l|l|l|l|l|}
\hline $\begin{array}{l}\text { The user shows more interest in virtual than in physical } \\
\text { relationships }\end{array}$ & 0 & 1 & 2 & 3 & 4 & 5 & 6 & 7 & 8 & 9 & 10 \\
\hline $\begin{array}{l}\text { The user enjoys virtual relations more than in physical } \\
\text { relationships }\end{array}$ & 0 & 1 & 2 & 3 & 4 & 5 & 6 & 7 & 8 & 9 & 10 \\
\hline $\begin{array}{l}\text { The user invests more time in virtual relationships than in } \\
\text { physical ones }\end{array}$ & 0 & 1 & 2 & 3 & 4 & 5 & 6 & 7 & 8 & 9 & 10 \\
\hline $\begin{array}{l}\text { The user shows their emotions more easily in the virtual } \\
\text { world than in the physical world }\end{array}$ & 0 & 1 & 2 & 3 & 4 & 5 & 6 & 7 & 8 & 9 & 10 \\
\hline $\begin{array}{l}\text { The user says what they think more easily in the virtual world } \\
\text { than in the physical world }\end{array}$ & 0 & 1 & 2 & 3 & 4 & 5 & 6 & 7 & 8 & 9 & 10 \\
\hline $\begin{array}{l}\text { The user pays more attention to virtual conversations than } \\
\text { ones in the physical world }\end{array}$ & 0 & 1 & 2 & 3 & 4 & 5 & 6 & 7 & 8 & 9 & 10 \\
\hline The user avoids conflicts by relating with others virtually & 0 & 1 & 2 & 3 & 4 & 5 & 6 & 7 & 8 & 9 & 10 \\
\hline $\begin{array}{l}\text { The user prefers to relate with others who share their love of } \\
\text { technology }\end{array}$ & 0 & 1 & 2 & 3 & 4 & 5 & 6 & 7 & 8 & 9 & 10 \\
\hline
\end{tabular}

\section{ICT IN THE EDUCATION SETTING}

49. In case of studying, rate to what extent the use of technologies affects your educational environment, in each of the following statements $(0=$ nothing and $10=$ much $)$ :

\begin{tabular}{|l|l|l|l|l|l|l|l|l|l|l|l|}
\hline I skip the rules set by the center on the use of technologies & 0 & 1 & 2 & 3 & 4 & 5 & 6 & 7 & 8 & 9 & 10 \\
\hline They have caught my attention & 0 & 1 & 2 & 3 & 4 & 5 & 6 & 7 & 8 & 9 & 10 \\
\hline Grades have gone down & 0 & 1 & 2 & 3 & 4 & 5 & 6 & 7 & 8 & 9 & 10 \\
\hline I find it harder to concentrate on studies & 0 & 1 & 2 & 3 & 4 & 5 & 6 & 7 & 8 & 9 & 10 \\
\hline I find it harder to pay attention in class & 0 & 1 & 2 & 3 & 4 & 5 & 6 & 7 & 8 & 9 & 10 \\
\hline I find it harder to memorise concepts & 0 & 1 & 2 & 3 & 4 & 5 & 6 & 7 & 8 & 9 & 10 \\
\hline I don't do homework & 0 & 1 & 2 & 3 & 4 & 5 & 6 & 7 & 8 & 9 & 10 \\
\hline I skip class & 0 & 1 & 2 & 3 & 4 & 5 & 6 & 7 & 8 & 9 & 10 \\
\hline I don't want to study anymore & 0 & 1 & 2 & 3 & 4 & 5 & 6 & 7 & 8 & 9 & 10 \\
\hline I don't interact with classmates & 0 & 1 & 2 & 3 & 4 & 5 & 6 & 7 & 8 & 9 & 10 \\
\hline
\end{tabular}

\section{ICT IN THE WORK SETTING}

50. In case of having a job, rate to what extent the use of technologies affects your work environment, in each of the following statements $(0=$ nothing and $10=$ much $)$

\begin{tabular}{|l|l|l|l|l|l|l|l|l|l|l|l|}
\hline Skip work & 0 & 1 & 2 & 3 & 4 & 5 & 6 & 7 & 8 & 9 & 10 \\
\hline Stop doing my job & 0 & 1 & 2 & 3 & 4 & 5 & 6 & 7 & 8 & 9 & 10 \\
\hline Arrive at work late & 0 & 1 & 2 & 3 & 4 & 5 & 6 & 7 & 8 & 9 & 10 \\
\hline Am tired & 0 & 1 & 2 & 3 & 4 & 5 & 6 & 7 & 8 & 9 & 10 \\
\hline Have conflicts with colleagues & 0 & 1 & 2 & 3 & 4 & 5 & 6 & 7 & 8 & 9 & 10 \\
\hline Have conflicts with boss & 0 & 1 & 2 & 3 & 4 & 5 & 6 & 7 & 8 & 9 & 10 \\
\hline Have had a workplace accident & 0 & 1 & 2 & 3 & 4 & 5 & 6 & 7 & 8 & 9 & 10 \\
\hline Doesn't want to go to work & 0 & 1 & 2 & 3 & 4 & 5 & 6 & 7 & 8 & 9 & 10 \\
\hline
\end{tabular}




\section{References}

1. Oliva, A.; Hidalgo, M.V.; Moreno, C.; Jiménez García, L.; Jiménez Iglesias, A.; Antolín, L.; Ramos, P. Uso y Riesgo de Adicciones a Las Nuevas Tecnologías Entre Adolescentes y Jóvenes Andaluces. 2012. Available online: https://idus.us.es/xmlui/bitstream/handle/11441/67723/uso_riesgo.pdf?sequence=1\&isAllowed=y (accessed on 17 January 2020).

2. Kuss, D.; Van Rooij, A.; Shoter, G.; Griffiths, M.; Van Mheen, D. Internet addiction in adolescents: Prevalence and risk factors. Comput. Hum. Behav. 2013, 29, 1987-1996. [CrossRef]

3. Wittek, C.T.; Finserås, T.R.; Pallesen, S.; Mentzoni, R.A.; Hanss, D.; Griffiths, M.D.; Molde, H. Prevalence and predictors of video game addiction: A study based on a national representative sample of gamers. Int. J. Ment. Health Addict. 2015, 14, 672-686. [CrossRef] [PubMed]

4. Argumosa-Villar, L.; Boada-Grau, J.; Vigil-Colet, A. Exploratory investigation of theoretical predictors of nomophobia using the Mobile Phone Involvement Questionnaire (MPIQ). J. Adolesc. 2017, 56, $127-135$. [CrossRef] [PubMed]

5. Díaz, V.M.; Gea, E.M.V.; Requena, B.E.S. Uso problemático del smartphone en estudiantes universitarios. Rev. Esp. Drogodepend. 2018, 43, 62-76.

6. Matalí, J.L.; García, S.; Marín, M.; Pardo, M. Adicción a las nuevas tecnologías: Definición, etiología y tratamiento. In Las nuevas tecnologías en niños y adolescentes. In Guía Para Educar Saludablemente en una Sociedad Digital; Roca, G., Ed.; Hospital Sant Joan de Déu: Barcelona, Spain, 2015; pp. 111-121. Available online: http://www.codajic.org/sites/www.codajic.org/files/Las\%20nuevas\%20tecnolog\%C3\%ADas\%20en\% 20\%20ni\%C3\%B1os\%20y\%20adolescentes.pdf (accessed on 17 January 2020).

7. Durkee, T.; Kaess, M.; Carli, V.; Parzer, P.; Wasserman, C.; Floderus, B.; Apter, A.; Balazs, J.; Barzilay, S.; Bobes, J.; et al. Prevalence of pathological Internet use among adolescents in Europe: Demographic and social factors. Addiction 2012, 107, 2210-2222. [CrossRef] [PubMed]

8. Frangos, C.C.; Frangos, C.C.; Sotiropoulos, I. Problematic internet use among Greek university students: An ordinal logistic regression with risk factors of negative psychological beliefs, pornographic sites, and online games. Cyberpsychol. Behav. Soc. Netw. 2011, 14, 51-58. [CrossRef]

9. Dong, G.; Wang, J.; Yang, X.; Zhou, H. Risk personality traits of Internet addiction: A longitudinal study of Internet-addicted Chinese university students. Asia-Pac. Psychiatry Off. J. Pac. Rim Coll. Psychiatr. 2013, 5, 316-321. [CrossRef]

10. Lee, K.; Lee, H.-K.; Gyeong, H.; Yu, B.; Song, Y.-M.; Kim, D. Reliability and validity of the Korean version of the Internet Addiction Test among college students. J. Korean Med Sci. 2013, 28, 763-768. [CrossRef]

11. Lam-Figueroa, N.; Contreras-Pulache, H.; Mori-Quispe, E.; Nizama-Valladolid, M.; Gutiérrez, C.; Hinostroza-Camposano, W.; Torrejón Reyes, E.; Hinostroza-Camposano, R.; Coaquira-Condori, E.; Hinostroza-Camposano, W.D. Adicción a Internet: Desarrollo y validación de un instrumento en escolares adolescentes de Lima, Perú. Rev. Peru. Med. Exp. Salud Pública 2011, 28, 462-469. [CrossRef]

12. Puerta-Cortés, D.X.; Carbonell, X. El modelo de los cinco grandes factores de personalidad y el uso problemático de Internet en jóvenes colombianos. Adicciones 2014, 26, 54-61. [CrossRef]

13. Yao, Z.; Zhong, M. Loneliness, social contacts and Internet addiction: A cross-lagged panel study. Comput. Hum. Behav. 2014, 30, 164-170. [CrossRef]

14. Fundación Pfizer. La Juventud y Las Redes Sociales, en Internet. 2009. Available online: https://www.fundacionpfizer.org/sites/default/files/pdf/educacion/informe_final_encuesta_juventud_ y_redes_sociales.pdf (accessed on 17 January 2020).

15. OCDE/OECD. Students, Computers and Learning: Making the Connection, PISA; OECD Publishing: Paris, France, 2015.

16. Instituto Nacional de Estadística. Encuesta sobre Equipamiento y Uso de Tecnologías de Información y Comunicación en los Hogares. Año 2016. 2016. Available online: http://www.ine.es/prensa/np991.pdf (accessed on 17 January 2020).

17. Echeburúa, E.; de Corral, P. Adicción a las nuevas tecnologías y a las redes sociales en jóvenes: Un nuevo reto. Adicciones 2010, 22, 91. [CrossRef] [PubMed]

18. Marín, V.; Sampedro, B.E.; Muñoz, J.M. ¿Son adictos a las redes sociales los estudiantes universitarios? Rev. Complut. Educ. 2015, 26, 233-251. [CrossRef] 
19. Suriá, R. Disability in young people, the risk of excessive Internet use? Health Addict. y Drog. 2015, 15, 15-24. [CrossRef]

20. Muñoz-Miralles, R.; Ortega-González, R.; Batalla-Martínez, C.; López-Morón, M.; Manresa, J.; Torán-Monserrat, P. Acceso y uso de nuevas tecnologías entre los jóvenes de educación secundaria, implicaciones en salud: Estudio JOITIC. Aten. Primaria 2014, 46, 77-88. [CrossRef] [PubMed]

21. Batalla, C.; Muñoz, R.; Ortega, R. El riesgo de adicción a nuevas tecnologías en la adolescencia: ¿debemos preocuparnos? FMC Form. Med. Continuada Aten. Primaria 2012, 19, 519-520. [CrossRef]

22. Carbonell, X.; Fúster, H.; Chamarro, A.; Oberst, U. Adicción a Internet y móvil: Una revisión de estudios empíricos españoles. Papeles Psicólo. 2012, 33, 82-89. Available online: http://www.papelesdelpsicologo.es/ pdf/2096.pdf (accessed on 17 January 2020).

23. García del Castillo, J.A. Adicciones tecnológicas: El auge de las redes sociales. Health Addict. 2013, 13, 5-14. [CrossRef]

24. Chen, L.; Ho, S.S.; Lwin, M.O. A meta-analysis of factors predicting cyberbullying perpetration and victimization: From the social cognitive and media effects approach. New Med. Soc. 2016, 19, 1194-1213. [CrossRef]

25. Carbonell, X.; Chamorro, A.; Griffiths, M.; Oberst, U.; Cladellas, R.; Talarn, A. Problematic Internet and cell phone use in Spanish teenagers and Young studentes. An. Psicol. 2012, 28, 789-796. [CrossRef]

26. Villa, M.; Suárez, C. Risk factors in the problematic use of Internet and phone in Spanish adolescents. Revista Iberoamericana de Psicología y Salud 2016, 7, 69-78. [CrossRef]

27. López-Fernández, O.; Freixa-Blanxart, M.; Honrubia-Serrano, M.L. The problematic internet entertainment use scale for adolescents: Prevalence of problem internet use in Spanish high school students. Cyberpsychol. Behav. Soc. Netw. 2013, 16, 108-118. [CrossRef] [PubMed]

28. Observatorio Europeo de las Drogas y las Toxicomanías. El Problema de la Drogodependencia en Europa. Informe Anual 2011; Oficina de Publicaciones de la Unión Europea: Luxembourg, 2011.

29. Bisquerra, R. Metodología de la Investigación Educativa; La Muralla: Madrid, Spain, 2005.

30. Hernández, R.; Fernández, C.; Baptista, P. Metodología de La Investigación; McGraw-Hill Interamericana: México, Mexico, 2006.

31. Teddlie, C.; Tashakkori, A. Foundations of Mixed Methods Research. Integrating Quantitative and Qualitative Approaches in the Social and Behavioral Sciences; Sage: Thousand Oaks, CA, USA, 2009.

32. Kaplan, B.; Duchon, D. Combining qualitative and quantitative in onformation Systems rearch: A case study. MIS Q. 1988, 12, 571-586. [CrossRef]

33. Greene, J.C.; Caracelli, V.J. Making paradigmatic sense of Mixed Methods practice. In Handbook Mixed Methods in Social and Behavioral Research; Tashakkori, A., Teddlie, C., Eds.; Sage: Thousand Oaks, CA, USA, 2003; pp. 91-110.

34. Ruiz, C. Instrumentos de Investigación Educativa: Procedimientos Para su Diseño y Validación; CIDEG: Barquisimeto, Venezuela, 2002.

35. Escobar, J.; Cuervo, A. Validez de contenido y juicio de expertos: Una aproximación a su utilización. Av. Med. 2008, 6, 27-36.

36. Cooke, R.M.; Goossens, L.L.H.J. TU Delft expert judgment data base. Reliab. Eng. Syst. Saf. 2008, 93, 657-674. [CrossRef]

37. Skjong, R.; Wentworth, B. Expert Judgement and Risk Perception. 2000. Available online: http://research.dnv. com/skj/Papers/SkjWen.pdf (accessed on 17 January 2020).

38. Cronbach, J.L. Coefficient alpha and the internal structure of test. Psychometrika 1951, 16, 297-334. [CrossRef]

39. Rodríguez, G.; Gil, J.; García, E. Metodología de la Investigación Cualitativa; Aljibe: Málaga, Spain, 1996.

40. McMillan, J.; Schumacher, S. Investigación Educativa. Una Introducción Conceptual; Pearson Educación: Madrid, Spain, 2006.

41. Nunnally, J.C. Psychometric Theory; McGraw-Hill: New York, NY, USA, 1978.

42. Peris, M.; Maganto, C.; Garaigordobil, M. Escala de riesgo de adicción-adolescente a las redes sociales e internet: Fiabilidad y validez. Rev. Psicol. Clín. Para Niños Adolesc. 2018, 5, 30-36. [CrossRef]

43. Jiménez, V.; Alvarado, J.M.; Llopis, C. Validación de un cuestionario diseñado para medir frecuencia y amplitud del uso de las TIC. Rev. Electr. Tecnol. Educ. 2017, 61,1-14. [CrossRef]

44. Arandas, M.; Fuentes, V.; García-Domingo, M. ¿No sin mi Smartphone?: Elaboración y validación de la Escala de Dependencia y Adicción al Smartphone (EDAS). Ter. Psicol. 2017, 35, 35-45. [CrossRef] 
45. Ruiz de Miguel, C. Perfil de uso del teléfono móvil e internet en una muestra de universitarios españoles: ¿usan o abusan? Bordón 2016, 68, 131-145. [CrossRef]

46. Amendola, S.; Spensieri, V.; Guidetti, V.; Cerutti, R. The relationship between difficulties in emotion regulation and dysfunctional technology use among adolescents. J. Psychopathol 2019, 25, 10-17.

47. Alonso, C.; Romero, E. Problematic Technology Use in a clinical sample of children and adolescents. Personality and behavioral problems associated. Actas Esp. Psiquiatr. 2017, 45, 62-70. [PubMed]

(C) 2020 by the authors. Licensee MDPI, Basel, Switzerland. This article is an open access article distributed under the terms and conditions of the Creative Commons Attribution (CC BY) license (http://creativecommons.org/licenses/by/4.0/). 